\title{
ACKNOWLEDGMENTS
}

Many people have helped us compile this Lexicon, yet it has many limitations of which we are painfully aware. We regard this as a preliminary effort, to be continued by Nukuoro students of their own language.

Nearly every person on the atoll contributed materially to this project. In addition to those who helped with early efforts to compile word lists, or with later efforts to verify words of which we were uncertain, many adults and school children helped collect specimens of flora and fauna that were sent to taxonomists for identification. Although there is insufficient space to record the names of all these generous people, we must mention the following persons who were especially helpful: Adisa, Adonisi, Aginesi, Aidele, Alege, Anton, Augusi, Bamala, Bodegi, Dala, Debalalo, Debola, Edelina, Ele, Eliodi, Gininga, Hagadau, Hellena, Hosea, Ioela, Iosua, Ivede, Madili, Maea, Nett, Otto, Salina, Sisugo, Sosese, Sulae, Uisili.

Topias Soulik began the compilation of this Lexicon, on a volunteer basis, during 1963 - 1966 while I was engaged in anthropological research on Nukuoro Atoll. We worked together during 1967 - 1969 at the Pacific and Asian Linguistics Institute, University of Hawaii, where he held the position of research associate. The final editing and writing of the introductory material and appendices were done by me during the summers of 1971 and 1972 at the Department of Linguistics, University of Hawaii, under the sponsorship of the Pacific and Asian Linguistics Institute.

Systems design and programing assistance were most ably provided by Robert Hsu and Ann Peters of the Pacific and Asian Linguistics Institute. The clerical labor of this project, during 1967 - 1969, 


\section{Nukuoro Lexicon}

fell on the able shoulders of Elaine Sommer; Jean Miyano and Gary L. Smith (through the courtesy of Freda R. Hellinger) provided additional, much needed, help in the summer of 1971. In the summer of 1972 I was fortunate to have the help of Ann Ikuta, Sharon Watanabe, Karen Young, and Cynthia Dalrymple.

Many taxonomists were generous with their time in identifying specimens. Nukuoro birds were identified from specimens by Robert W. McFarlane of the Department of Zoology, University of Florida. Nukuoro plant specimens were identified by F. Raymond Fosberg of the Smithsonian Institution. Shell specimens were identified by Alison Kay, Department of General Science, University of Hawaii. Fishes were identified, to the extent possible from color slides, by Gareth J. Nelson, Robert S. Jones, and William Van Heukelam - all of the Department of Zoology, University of Hawaii. Identification of miscellaneous marine invertebrates was provided (from color slides) by Lucius G. Eldredge of the Department of Zoology, University of Guam. Insects were identified from specimens by Setsuko Nakata of the Bernice P. Bishop Museum, Honolulu, and by her collaborators:W. A. Steffan (mosquitos), H. Sima (flies), and J. W. Beardsley (scale insects).

My work on this Lexicon in 1963 - 1966 was done during the tenure of a predoctoral fellowship from the U.S. Public Health Service (National Institutes of Mental Health). In the summer of 1967 further assistance was provided by the Graduate School Research Fund of the University of Washington. The major portion of the project was completed in 1967 - 1969 with the assistance of a research grant (GS - 1831) from the National Science Foundation, during the tenure of a postdoctoral fellowship from the American Council of Learned Societies and a visiting appointment at the Pacific and Asian Linguistics Institute (PALI) of the University of Hawaii. I am grateful to the director of PALI at that time, Howard McKaughan, for his extraordinary efforts on my behalf. During the summer of 1971, my work was supported by the Department of Education, Trust Territory of the Pacific Islands.

My colleagues at PALI and in the Department of Linguistics at the University of Hawaii have invariably provided an invigorating and cheerful environment in which to work. The PALI office; under the able direction of Joanne Nakagawa, was unfailingly helpful.

Publication of this work was made possible by the Department of Education, Trust Territory of the Pacific Islands; and by the Pacific and Asian Linguistics Institute, through the good offices of 
its current director, Donald Topping, without whose help and encouragement this work might never have appeared.

Editorial suggestions of great value were provided by Byron W. Bender, Raymonde Carroll, George W. Grace, Michael D. Lieber, and Donald M. Topping.

Vern CARRoll

Pacific and Asian Linguistics Institute University of Hawaii August 1972 
